\title{
WHEN THE FUTURE BECOMES THE PRESENT OF THE ENVIRONMENTAL CRISIS. THE JURISPRUDENCE OF THE BRAZILIAN SUPREME COURT AND THE FUTURE DIMENSION OF THE RIGHT TO THE ENVIRONMENT
}

\section{QUANDO O FUTURO SE TORNA O PRESENTE DA CRISE AMBIENTAL. A JURISPRUDÊNCIA DO SUPREMO TRIBUNAL FEDERAL E A DIMENSÃO FUTURA DO DIREITO AO MEIO AMBIENTE}

\author{
Clarissa Marques ${ }^{1}$
}

\begin{abstract}
The environmental crisis stems from a human development process. The risk that is assumed is the commitment of the future generations. However, the guarantee of the quality of the future generations is shown as a time-present problem. Another aspect of this coexistence between present and future is the formation of the subject of the right to the environment and its analysis by the jurisprudence of the Brazilian Supreme Court. Since solidarity acts in the law as an intergenerational bond is important to note how this jurisprudence has interpreted this "new subject" and how the future dimension of the right to the environment has been interpreted. The objective of this paper is to emphasize the need to "resituate" the relationship between man and the natural order in the face of environmental crisis and how necessary it is to take responsibility for the future time, even with regard to unborn subjects. It is hoped that it will contribute to the analysis of the jurisprudence on the need to take on responsibility for the transgenerational subject and its right to the environment, being that the future tense becomes the present of this new epoch.
\end{abstract}

Keywords: environment; sustainability; risks; subject; environmental crisis.

\section{Resumo}

A crise ambiental decorre de um processo humano de desenvolvimento. O risco que se assume é o comprometimento das gerações futuras. No entanto, a garantia da qualidade futura das gerações mostra-se como problema do tempo-presente. Outro aspecto dessa coexistência entre presente e futuro é a formação do sujeito do direito ao meio ambiente e sua análise pela jurisprudência do Supremo Tribunal Federal. Uma vez que a solidariedade age no Direito como um vínculo intergeracional é importante observar como essa jurisprudência tem interpretado este "novo sujeito" e de que forma a dimensão futura do direito ao meio ambiente tem sido interpretada. $O$ objetivo do presente trabalho é enfatizar a necessidade de "ressituar" a relação entre o homem e a ordem natural diante da crise ambiental, bem como o quanto é preciso assumir a responsabilidade por um tempo por vir, inclusive, no que se refere aos sujeitos não-nascidos. Espera-se com isso contribuir para a análise da jurisprudência quanto à necessidade de assumir o sujeito transgeracional do direito ao ambiente, uma vez que o tempo futuro torna-se o presente desta nova era.

Palavras-chave: meio ambiente; sustentabilidade; riscos; sujeito; crise ambiental.

\footnotetext{
${ }^{1}$ PostDoctoral Researcher at New School for Social Research - NY (Scholarchip funded by CAPES-Brazil), PhD in Law (UFPE-Brazil), Law Professor at Faculdade Damas (Pernambuco-Brazil) and FACIPE (PernambucoBrazil), environmental lawyer. This work was supported by CAPES-Brazil. E-mail: marquesc@newschool.edu
} 


\section{INTRODUCTION: WHEN THE FUTURE BECOMES A PRESENT CRISIS}

The realization that the future of the environmental crisis is already part of the present, or, in environmental terms, present and future lack a well-defined temporal border, resulting in some implications pertaining to the right to the environment. This "state of crisis" is marked, among other things, by the need for an analysis of the future effects of environmental risks. Additionally, an analysis of existing obligations, not as a duty that is yet to come, implies another need that is no less urgent: the transgenerational analysis of the right to the environment and the consequent formation of a "new subject". After the law had guaranteed the right to the environment, the legal doctrine had to confront a new type of subject of law, who partly exists and is also partly unborn. The identification of the community and government as subjects of constitutional duty to environmental preservation, as well as the present and future generations as beneficiaries of that duty, gives rise to the question of the existence of an intergenerational bond in the right to the environment. The figure of a "total subject", not limited temporally, who is partly "unborn", presents intergenerational equity. That is, the sustainable use of resources to allow future access by the generations, which are yet to come.

As a reaction to what has been called the "risk scenario", the international community turned to the concept of sustainable development in the realization that humanity could no longer follow the growth model once adopted by the industrialization process. In this sense, this article considers the concept of sustainability, based on solidarity as an intergenerational bond, whose dimension of ethical responsibility requires new considerations, especially about future time. Furthermore, it aims to underline the right to the environment as transgenerational and the need of a jurisprudence that includes the future terms of this right in its decision-making. This project exceeds the proximity of subjects and approaches future generations. Lastly, it emphasizes the bond between the present and future, and points to a "new subject" in the environmental crisis scenario, which can be considered a "state of crisis" or even as an "evil".

"Evil" 2 , as conceptualized by Hans Jonas, is identified as the environmental crisis, which coexists with the ideology of development and brings the future crisis into the present. Identifying the malum is a much simpler process than identifying the bonum, since imposing its presence with all its effects provokes fear, while what is commonly considered "good" many times remains

2 The idea of evil used here is based on the theoretical construction of Hans Jonas about what the author called "Heuristics of Fear". O princípio responsabilidade. Ensaio de uma ética para a civilização tecnológica. Rio de Janeiro: Contraponto, 2011, p. 71. 
unknown due to its discreet presence. Accepting a malum is not an easy task. This might be the cover letter of what has been called an environmental crisis: a non-desired and imperative "evil", manifested in the present and simultaneously presenting us a future, which in spite of being unlived, already exists due to environmental risks that are yet to come but are already considered current issues. The thought of a crisis makes us face the fear of an "environmental evil" that has been identified and has brought the future into the present.

This crisis is far from being only another natural disaster or a series of catastrophes. At first sight, it seems possible to consider the ecological crisis a spontaneous manifestation of natural order. This spontaneity is due to the fact that it is impossible for man to exert control over all natural manifestations. It is the non-human world in action, which for some may actually mean a return to the magical state of nature, to the association of mystic and religious beliefs of natural order. On the other hand, what must also be considered is that the spontaneous nature of this non-human world might not be of such a spontaneous character. Natural manifestations can be understood as reactions to the human and ideological developmental process; the natural order reacting to the human behaviour of trying to achieve non-human development. The crisis is an ascertainment of the ideology of development, or as Lyotard explains, one of the dimensions of the process of the Inhuman (LYOTARD, 1991). Additionally, it has positioned itself in absentia of nonhuman elements as well as the relationship between human and non-human nature.

Thus, "environmental evil" is partly the result of the break between human and nonhuman, of modern rationality that has resulted in the creation of two distinct "worlds": the world of subjects and the one of objects they will have ownership over. This is one of the consequences brought about by modernity; a result of how it has behaved nature-wise throughout time; conceptually distant, however, close enough to exploit it. "Evil", which has been closely identified through environmental incidents that directly affect numerous lives, including those of the unborn, is a result of the rupture between man and nature. The distance created between these "two worlds" brings us closer to the detrimental effects incurred by human behaviour concerning social order, including future risks.

A second stage of this so-called environmental crisis will be considered as "non-desired", intending the consequences and limitations caused by this "identified evil". In other words, once the environmental crisis is in fact not desired, but rather imposed through its manifestations, causing fear when it comes to fruition and leaves us no choice. Notwithstanding, this fear is not always far-reaching, and often prefers to wait for "future evil" to become present to only then 
become "non-desired". The "non-desire" focuses on what stands before our eyes and can thus be seen as non-desired, encountering limitations in time. To be sure, "environmental evil" consists of two dimensions; that of the actual "evil" unfolding, and that of the consequent "non-desire" of it and the lack of action brought about by this "non-desire".

Within the two phases of identifying "evil" and "non-desired evil", we find the idea of a crisis. Established among natural manifestations, the understanding of an environmental crisis points towards a scenario that is further and further away from the idea of spontaneous disasters. Spontaneity underlies the human construction of this crisis throughout history, culminating with the perpetuation of its effects over time once, present and future coexist. What now needs to be observed by jurisprudence, in light of the right to the environment, which provokes an analysis of a "new subject", is a subject who is both part of the present and part of the future. In this sense, the future of the environmental crisis becomes present and its future subjects already exist.

\section{THINGS OF NATURE AND THE NATURE OF THINGS: THE RISK OF MAYBE}

As Isabelle Stengers stated, "these are strange times" (2015, p. 07), as if we were living two different stories enacted in a world that has become "global". One of them is known by everyone, highlighted by competitiveness and the idea of development, but at the same time fearful of its consequences, ever-growing social differences, pollution, pesticides poisoning, depletion of water supplies and the evident climate changes, to name a few and why not also the migration, the environmental refugees and fragmented urban life (HARVEY, 2013). The second story can be clearly identified when it comes down to the facts, but obscure when it comes to answers of what has been happening (STENGERS, 2015) - the so-called present and future risks, this well-known uncertainty. This "time of catastrophes" is highlighted by the need to question what is clearly known as development and make it responsible for its consequences. It is the protest against how unsustainable this growth has presented itself. It is challenging to think of "a non barbaric future" and life after economic growth. These new times point towards a nature that needs to be protected against the damages caused by man, including the damage inflicted on urban spaces, concurrently upsetting us, as it questions our established knowledge and lifestyle (STENGERS, 2015). The reflection that arises concerns the time of things, since the so-called "environmental crisis" is not seen as a temporary phase of "evil" that needs to be overcome, but rather as a permanent "evil". 
In this sense, the environmental crisis represents a series of crisis in civilization, the Western mindset, modern rationality (BAUMAN, 2001), the economic model, the paradigm of distancing, which denied the relationships between subject/object, organism/environment and cause/effect (MOORE, 2015a). Thus, the environmental crisis distances itself from the conception of an autonomous and spontaneous ecological catastrophe ${ }^{3}$. Furthermore, is closer to the ascertainment that nature is negated and exploited from the conversion of a "being" into homo economicus (LEFF, 2006). It represents the need to rediscover the place which man must occupy in nature, as well as the necessity to resituate the human being in the world (GUZMÁN, 1995), his relationship with natural elements and his relationship with urban life built by the modern paradigms.

Modernity and enlightenment rationality have contributed to the increase in the gap between man and natural order, the fragmentation of nature and the objectification of the world (LEFF, 2006). Together with Descartes, a milestone in the emergence of modern science has been brought. Man is the center of the universe ${ }^{4}$ and nature is significantly reduced (FERRY, 2003) due to the prevalence of certain behaviour, such as domination and possession (SERRES, 1992). The scientific paradigm, thus, resulted in the creation of a rift between the human and the natural. In this isolation, the human world and the non-human world are observed separately. The first pertains to the role of subject, and the second to the object function available to be appropriated. It is as if the Cartesian dualism had created two compartments: in one a society without "natures", and in the other nature without humans. However, the so-called "environmental humanities" and social sciences added another element to this dualist debate: the world of environmental impacts, which reinforce the importance and legitimacy of the environment and its "crisis" as objects to be analysed (MOORE, 2015a). Additionally, in the case of the present article, the need for an analysis of the future dimension of one's right to the environment.

For a long time a divine presence was thought to protect nature. As it seems, a brief analysis of man's central role in modernity, placing nature in a secondary and distant position, leads to the belief that it was not possible to break the divine bond and simultaneously maintain

\footnotetext{
${ }^{3}$ Although the idea of catastrophe have not been received by this work, its doctrinal reception is quite common. "Il est impossible d'éviter une catastrophe climatique sans rompre radicalement avec les méthodes et la logique économique qui y mènent depuis cent cinquante ans". GORZ, André. Écologica. Paris: Galilée, 2008 , p. 29.

${ }^{4}$ According to Luc Ferry, "la modernité anthropocentriste est un total désastre". Le nouvel ordre écologique. L'arbre, l'animal et l'homme. Paris: Grasset, 2009, p. 32.
} 
the ties with non-human elements. God's death as brought by Nietzsche ${ }^{5}$, represents the need to state human superiority, including above nature. God ceased to exist in everything and nature became a human object of development and appropriation, a vision of the world in which man is the center of, what Eugene Thacker calls, "the world to us" (THACKER, 2011, p. 04).

In contrast to the fluid process in which we find ourselves, as Bauman states, where social structures and institutions face liquefaction, modernity proposes stability. Through rigid forms and means, it bridges the gap between the human and the natural (BAUMAN, 2005) distancing man from the natural order and emphasizing the idea that nature is an object to be possessed and a category to be exploited. Thus, one of the highlights of these modern times is what we call Cartesian dualism, characterized by the tendency to strongly delimit what is human and what is natural, which Jason Moore identified as an "epistemic rift" (MOORE, 2015b). This rift is a means to try to name the separation between direct producers and the means of production, which according to the author explains why the divorce between nature and society was consolidated in the very start of capitalism. One of its assumptions is the sharp division between the natural order, considered a source of free raw material available for appropriation and the economic order, conceived as value produced by men for men. Capitalism undertook the modern premise of separating human nature - seen as social-cultural and historic - and non-human nature, regarded as objectively given and ahistorical (FRASER, 2014). "It triggered what is now nicknamed as 'Anthropocene', a brand new geologic era in which human activity has a decisive impact on

\footnotetext{
${ }^{5}$ In "Thus Spoke Zarathustra", Nietzsche talks about what he called the "death of God" and announces the Superman. When descending the mountains, Zarathustra finds an old man in the woods that, among others, asks him some questions: "No stranger to me is this wanderer: many years ago passed he by. Zarathustra he was called; but he hath altered. Then thou carriedst thine ashes into the mountains: wilt thou now carry thy fire into the valleys? Fearest thou not the incendiary's doom. Yea, I recognise Zarathustra. Pure is his eye, and no loathing lurketh about his mouth. Goeth he not along like a dancer? Altered is Zarathustra; a child hath Zarathustra become; an awakened one is Zarathustra: what wilt thou do in the land of the sleepers? As in the sea hast thou lived in solitude, and it hath borne thee up. Alas, wilt thou now go ashore? Alas, wilt thou again drag thy body thyself? Zarathustra answered: "I love mankind". In this passage, Zarathustra is no longer carried by sea, which is one of the representations of the natural order and is questioned about the desire to return to drag the body, an autonomous, spontaneous and rational movement instead of moving waters. His response confirms the choice of the human dimension: "I love mankind". Elsewhere is shown interested in the possibility of the old man did not know the death of God. When Zarathustra was alone, however, he said to his heart: "Could it be possible! This old saint in the forest hath not yet heard of it, that God is dead!". Then announces the Superman and identifies with the sense of the earth, summoning all to remain faithful to the earth and do not believe those who speak of land above hopes, God died. In: https://en.wikisource.org/wiki/Thus_Spake_Zarathustra/Prologue Accessed in: 04/04/2016.
} 
ecosystems and Earth's atmosphere" ${ }^{6}$ or "Capitalocene", the era of capital (MOORE, 2015b). However, this same capitalism "is confronted with a future whose threats gained a terribly concrete aspect in a few years" (STENGERS, 2015, p. 18).

To Bataille, the modern industrial world was the bourgeois world, and it created the world of things (BATAILLE, 1988). In other words, it generated the objectification of natural elements, making man "master of such things". The bourgeois world is characterized by the constant need for new markets. This social class intensified cosmopolitan features of production and consumption, and the exploitation that surpassed the limits of appropriation of the non-human world by man. Economic growth was proposed through a paradigm of the denial of nature: a mechanistic view (LEFF, 2006) that is drawn to the metaphysical idea of developing a theory of the world as it is, with descriptiveness as its major goal. Additionally, a concern of defining the world as it is, rather than how it seems to us. In this sense, metaphysics invented the world in the first place (GABRIEL, 2015), and in this invention it made nature a distant part of the whole to which it was entitled as an object of possession by man. Alternatively, Lyotard asks, "what if man, in the humanistic sense, becomes inhuman? Or what if man is deemed to be inhuman?" (LYOTARD, 1991, p. 08) This takes us back to the discussion surrounding what was conventionally called environmental crisis. The author does not mention the crisis specifically, but one of the inhuman dimensions that, according to him, is called development and will hereby be regarded within the scenario of the so-called environmental crisis. "Development is the ideology of the present time, it realizes the essential of metaphysics, which was a line of thought pertaining to forces, much more than to the subject" (LYOTARD, 1991, p. 08). Development, as an ideology, has contributed to the metaphysical detachment between subject and object, man and objectified nature - the modern break. In other words, is the environmental crisis a reflex of the inhuman development caused by human actions? At first sight, it is possible to consider the ideological crisis as a spontaneous manifestation of the natural order. On the other hand, the fact that the performance of this non-human world, which is naturally manifested, might not be identified as spontaneous. The catastrophes, which are usually called "natural", would actually be far from spontaneous processes and rather the effects of the human and ideological developmental process. To be sure, it would be the non-human world reacting to human behaviour in response to the idea of developing that world. Having said that, environmental

\footnotetext{
6 "It inaugurated what has now been dubbed the Anthropocene, an entirely new geological era in which human activity has a decisive impact on the Earth's ecosystems and atmosphere". FRASER, Nancy. Behind Marx's hidden abode. For an expanded conception of capitalism. New Left Review n. 86, Mar./Apr. 2014, p. 63.
} 
crises are a consequence of behaviour that exploits the "non-human" without considering the role of non-anthropocentric elements.

\section{WHEN FUTURE BECOMES A CIRCUMSTANCE OF THE PRESENT}

Modernity cemented and increased the tendency to categorize the propensity to definitions, reasoning through oppositions such as man-nature and subject-object. It forces us to become distant from natural elements in the name of a rationality in which nature takes the status of an object, and consequently, is profiteered. However, it is time to transcend the dichotomies and hypothesize the world as human and non-human simultaneously. This is becoming clear in the fact that environmental discourse has failed to bring about solutions. The simple conceptual division of the estrangement (man versus nature) does not sufficiently respond to the current environmental scenario. The crisis scenario requires a non-dualistic analysis, which is capable of interpreting "both modern compartments" as a whole. The integration between nature and society is analysed (LUKE, 2004) again, and this seems to be the point of crisis: humanity being led to rethink nonhuman elements beyond the categorization of available objects. Added to this is the need to rethink the temporal dimension, once the effects go beyond present time and to make the future a current problem. In addition, a need for an analysis of the right to the environment and its "new subject".

If modern society turned itself to the paradigm of distancing from the natural order (LEFF, 2006), transforming the non-human into something to be exploited, the current moment seems to formulate questions regarding what will hereby be called the "modern break". Contemporaneity, identified by some as post-modernity, highlighted by fluid concepts and complex social relationships, to name a few, underlines the modern rupture between subject and object, a strong break which makes us face ethical challenges. Simon Critchley warns the need for us to resist nihilist and pessimist temptation and face the tough reality of the world that points towards unfair violence all around, a growth in social and economical inequality, and reactionary behaviour towards what is understood as identity, only to name a few. A reality that questions the "health" of liberal democracy and presents a massive political disappointment (CRITCHLEY, 2012). Despite Critchley not referencing environmental degradation as one of the aspects of this contemporary reality, it should not be excluded either. In the wake of concern raised by Critchley about a motivational deficit that seems to involve ethical experience nowadays, one can question if, as a result, there would also be the emptying of moral reflection currently about an ethical pro future in 
environmental terms. Or, in legal terms, the difficulty in conceptualizing this transgenerational subject of the right to the environment.

Markus Gabriel in turn, considers contemporaneity not as post-modernity, but as New Realism. Post modernity would have been an attempt to restart, overcoming the failure of most modern human promises, from religion to totalitarian experiences. A theoretical alternative to free us from the metaphysical belief that life has a specific meaning (GABRIEL, 2015). For the author, post-modernism was one more variation of metaphysics, as it would have been based on the general formula of constructivism. He, in turn, considers that facts are non-existing in their essence, they are all results of our perception and nothing exists beyond our discourses (GABRIEL, 2015). When looking at the world unilaterally, metaphysics and constructivism caused a simplification of reality. In other words, the world without spectators (metaphysics) or, equally one-sided, the world of viewers (constructivism). On the other hand, New Realism presents itself as a perspective that takes the world in a non-exclusive way, for while the world has spectators, facts that do not interest them exist regardless of their will and perception. The old realism (metaphysics) focused on a world without spectators, and constructivism, according to Markus Gabriel, is rooted on the illusion of its spectators (GABRIEL, 2015).

Notwithstanding, when it comes to analysing what is here regarded as an environmental crisis resulting from "modern collapse" and is responsible for the distance between the "human" and "non-human" world, New Realism seems to present us with a new Narcissus. It is presented as another alternative centred on the conception of two worlds distanced by appropriation and that disregards future time. In spite of considering that some facts in the world occur regardless of spectators' interest and will, its perspective has a defined date and time. Its concern is present time, which already exists and is manifesting itself, and may somehow reflect on Narcissus' mirror. The New Realism seems unable to turn itself towards future time easily. The latter is one of the major marks of the environmental crisis: one which besides emerging from the distance between man and nature, turns towards an uncertain and non-existing time, a time yet unlived and therefore not yet reflected on the water mirror that produces Nacissus' image, or, what could be called as a time of the unborn subjects.

The perspective of the world under this New Realism turns towards the sum of the facts that exist regardless of the perception of spectators, that is, real facts which have manifested themselves or are in the process of, and conversely, facts that suffer human perception. In other words, the only chance for the future time of the environmental crisis to be considered, is if this 
time arouses human attention or the spectator's interest, which might only occur when the future is not future, but has become the present. What this means, in legal terms, is that the unborn subjects wont be considered in the beginning. They will eventually arouse attention when they become existing persons. This is what could make, the transgenerational subject of the right to the environment, impractical.

New Realism lacks a third option: facts that will exist in the future, regardless of the perception given by present spectators and that will affect the lives of future ones, regardless of the interest that they have in such facts. This third alternative, however, is unviable for the simplification proposed by this theoretical alternative, once Narcissus' mirror cannot reflect what is yet to come. It cannot glimpse, for instance, one of the peculiarities of the environmental crisis, which is its capacity to make present and future coexist. That is, in environmental terms and admitting the conception proposed by the New Realism, the future gains space when its reflex can be foreseen, which means that the environmental future needs to become present, appear on humans interests' mirror, to then be a part of a critical analysis surrounding the environmental crisis. In this sense, the unborn subjects of the right to the environment would gain space when and only if they become existent subjects. In others words, this current conception about the present is not able to deal with the "new subject" of the right to the environment; a transgenerational subject that requires actions on behalf of present and future generations.

\section{SUSTAINABILITY, THE FUTURE DIMENSION OF THE RIGHT TO ENVIRONMENT AND THE JURISPRUDENCE OF THE BRAZILIAN SUPREME COURT}

The acknowledgement that the environmental crisis is one of the aspects of the crisis of the liberal Western model faces the hypothesis that it is necessary to rise to the challenge. This challenge involves considering the possibility of ethical coexistence between the non-human and future time and it assumes the obligation of sustainable behaviour, as well as, includes as subjects of the right to the environment those who are not yet born. It is necessary to consider the reunification of man and natural order and take responsibility for a time that is yet to come but given the circumstances of the crisis, is shown as present. The same analysis has to be executed with regards to the unborn subjects of the right to the environment, despite their non-existent condition; they should already be a part of the present considerations of that right.

Ironically, the crisis would be placed in the challenge of present and future coexisting; situated in a scenario which is already broken but integrates a future that is yet to come, as 
contradictory as it may seem. It might represent the difficulty in facing the fact that natural representation forms are not always under man's control. What is more that natural manifestations many times surpass the barrier of human desire and simply present themselves - in the present or future - regardless of their will. Or maybe, that the crisis finds a place beyond the understanding of the natural order and its own will, and will question what humanism has always thought had been deemed unquestionable: man (LYOTARD, 1991). However, the environmental crisis provokes, not only the need to question man's behaviour, but also the need to assume that the subject of the environmental right is composed, at the same time, by present and future actors. Again, present and future coexist.

As a sign of reaction to what has been called the "risk scenario", the international community turned to the concept of sustainable development ${ }^{7}$ in the realization that humanity could no longer follow the growth model adopted by the industrialization process. For Ignacy Sachs, sustainable development is one of three elements that make up the idea of development. In other words, development was formed by socially inclusive development, environmentally sustainable and economically sustainable elements (SACHS, 2009). The justification of Sachs, regarding socially inclusive development, would be that development goals are ethical and social. In addition, social progress would be promoted "based on an ethical postulate of synchronic solidarity with their generation" (SACHS, 2009, p. 23). It should be noted that converting the synchronic solidarity with their generation in an ethical postulate, in service of social progress, is not a theoretical possibility for the present article. The right to the environment is analyzed here from a perspective that goes beyond the present time, it turns also to the future dimension of the subjects and moves away from the indifference to the "unborn" subjects.

\footnotetext{
${ }^{7}$ V. GARNIER, Christian. De La nature au dévelopement durable: La construction d'un concept pératoire. In: BOITEUX, Marcel. L'homme et sa planète. Paris: PUF, 2003, p. 55. "Le développement durable signifie que la satisfaction des besoins humains d'aujourd'hui ne doit pás se faire au prix d'une destruction irréversible des ressources naturelles et d'une mise en péril des grands equilibres de la biosphère". SMOUTS, Marie-Claude. Le développement durable: valeurs et pratiques. In: SMOUTS, Marie-Claude. Le développement durable. Lês termes du débat. Paris: Armand Colin, 2008, p. 15. "Le développement durable peut être perçu comme de la croissance économique sous contrainte écologique. Dans cette perspective, II s'agit de respecter lês conditions de reproduction des écosystèmes et d'économiser les ressouces rares". GOUGUET, Jean-Jacques. Développement durable et décroissance. Deux paradigmes incommensurables. In: Pour un droit commun de I'environnement. Mélanges en I'honneur de Michel Prieur. Paris: Dalloz, 2007, p. 133. "Le développement durable, moins que un concept, designe plutôt un champ d'investigations et d'activités, reconfigurant ce que signifie l'humanisation sur fond d'une nature reconnue précieuse mais fragile". PIERRON, Jean-Philippe. Penser le développement durable. Paris: Ellipses, 2009, p. 16.
} 
Sustainability is based on a concept of solidarity as an intergenerational bond in the right to the environment and allows a new conception of an ethical responsibility that goes beyond the sphere of proximity of the subjects involved; it turns to future generations. A sense of solidarity guided by "non-reciprocity" with a view that is established between the present generations and those to come. The subjects of future generations to this extent, of course, do not yet exist, the timing remains impaired as what is proposed is a solidarity between the subjects of today towards the future. To put it differently, a relationship that breaks with the contractualist modern heritage and surpasses the reciprocity proposal, based on exchange between the poles of the juridical situation. It is true that the future generations in no way contribute to this quality of life. However, the author explains that for the desired social progress to become possible, it is necessary to respect "ecological conditionalities, environmental conditionalities from another ethical concept: the ethical concept of diachronic solidarity with future generations". In this sense, Sachs emphasizes this point with the idea of an environmental ethics and solidarity with future generations. He demonstrates that the promotion of an environmentally sustainable development requires the consideration of the need for a new ethical position. The result is solidarity that is mainly diachronic with future generations and thus not reciprocal.

The mandatory ethics of synchronic solidarity with the current generation amounted to diachronic solidarity with future generations, and for some, the ethical principle of responsibility for the future of all living species on Earth. In other words, the social contract which underpins the governance of our society should be complemented by a natural contract (SACHS, 2009, p. 49).

To Raffaele Bifulco, there is no doubt that the principle of sustainable development is structurally oriented towards the future. His proposal considers an economic component, a social component and an environmental component but also proposes the recognition of a fourth element: the intergenerational character that would cross the others transversely (BIFULCO, 2008). Thus, when environmental problems were seen not only as the inevitable result of scientific and technical growth and nature was recognized as a fragile condition, the proposal for an environmental protection policy gained ground. More than a scientific study of the situation, this policy appeals to ethics and law. That is, for an analysis of moral and legal norms that is able to drive our actions (LARRÈRE; LARRÈRE, 2009) through a reflective thinking that recognizes the links between the risks and the future; a diachronic proposal.

The Brazilian Constitution of 1988 promoted the perspective of sustainable development, when established in article 170, that the freedom of initiative is one of the foundations of the 
constitutional economic order, provided people comply with its principles, one of which is the protection of the environment. That is, freedom of enterprise is not disconnected from the environmental protection duty but subject to it and is one of its conditions; it is an immanent limit on the right to free enterprise. The Brazilian Supreme Court has even ruled to identify the limitation of freedom of initiative based on the principle of environmental protection:

Economic activity cannot be exercised without harmony with the principles to make effective the environmental protection. The safety of the environment can not be compromised by corporate interests or become dependent on purely economic nature of motivations, especially if it is present that economic activity, considered the constitutional discipline that governs it, is under conditions, among other general principles, of the principle that focuses on 'environmental protection' (CF, art. 170, VI), which translates broad and comprehensive concept of the notions of the natural environment, cultural environment, the artificial environment (urban space) and through the work environment. Doctrine. The juridical instruments of legal character and constitutional aim to enable the effective protection of the environment, so it does not alter the properties and attributes that are inherent, which would cause unacceptable compromising of the health, safety, culture, work and well- being of the population and would cause serious ecological damage to the environmental heritage, considered this in their physical or natural aspect ${ }^{8}$

The question of national development (Constitution, Article 3, II.) And the need to preserve the environmental integrity (Constitution, Article 225.): the principle of sustainable development as a factor getting the right balance between the requirements of economy and ecology. The principle of sustainable development, impregnated by an eminent constitutional character, finds a legitimizing support on international commitments made by the Brazilian government and is factor for getting the right balance between the demands of the economy and the ecology, under conditions, however, of the invocation of this postulate, when occurring conflict situation between

\footnotetext{
${ }^{8}$ ADI 3.540-MC, Rel. Min. Celso de Mello, julgamento em 1-9-2005, Plenário, DJ de 3-2-2006. "A atividade econômica não pode ser exercida em desarmonia com os princípios destinados a tornar efetiva a proteção ao meio ambiente. A incolumidade do meio ambiente não pode ser comprometida por interesses empresariais nem ficar dependente de motivações de índole meramente econômica, ainda mais se tiver presente que a atividade econômica, considerada a disciplina constitucional que a rege, está subordinada, dentre outros princípios gerais, àquele que privilegia a 'defesa do meio ambiente' (CF, art. 170, VI), que traduz conceito amplo e abrangente das noções de meio ambiente natural, de meio ambiente cultural, de meio ambiente artificial (espaço urbano) e de meio ambiente laboral. Doutrina. Os instrumentos jurídicos de caráter legal e de natureza constitucional objetivam viabilizar a tutela efetiva do meio ambiente, para que não se alterem as propriedades e os atributos que the são inerentes, o que provocaria inaceitável comprometimento da saúde, segurança, cultura, trabalho e bem-estar da população, além de causar graves danos ecológicos ao patrimônio ambiental, considerado este em seu aspecto físico ou natural".
} 
relevant constitutional values to an unremovable condition, which must not compromise or empty the essential content of one of the most significant fundamental rights: the right to preserve the environment, which translates well to the use of common general people to be safeguarded for the benefit of present and future generations ${ }^{9}$.

This decision illustrates how economic activity is paired with legal conditions, as the environment protection. However, it doesn't give prominence to the fact that the environmental protection involves a transgenerational subject. In fact, it only mentions, very discreetly, the importance of avoiding damages to the environmental heritage as well as the preservation of the environment for the benefit of present and future generations. It is worth noting that with this pronouncement the Supreme Court, which in addition to having identified sustainable development as a constitutional principle, highlighted its role in the international commitments made by Brazil and indicated its function to balance the promotion of the economy and the environment.

The recognition of future effects of the risks begins with the acceptance that the representation of the future hitherto adopted, whose control was given through reasonably foreseeable conditions, proves to be insufficient for the current state. "In contemporary societies, it is no longer possible to represent - the future - with certainty and security. Any such effort would be deductible in terms of only a simplified description of a probable or possible society" (LEITE; AYALA, 2002, p. 14). In addition to the rational management of natural resources, the notion of sustainability reflects on the legacy to be passed on to future generations. This would not be limited to a natural heritage of quality, but mainly to allow the possibility of choice. In other words, not creating irreversible situations (SMOUTS, 2008) for the future and preserving the intergenerational equity. More than the concern to ensure future choices, it seems necessary to overcome the modern paradigm subject-object, introducing a dialectical conception of man and nature (OST, 1995). This is so, that the domination and exploitation of one over the other is

\footnotetext{
${ }^{9}$ ADI 3.540-MC, Rel. Min. Celso de Mello, julgamento em 10-9-2005, Plenário, DJ de 3-2-2006. “A questão do desenvolvimento nacional (CF, art. 3ㅇ, II) e a necessidade de preservação da integridade do meio ambiente (CF, art. 225): O princípio do desenvolvimento sustentável como fator de obtenção do justo equilíbrio entre as exigências da economia e as da ecologia. O princípio do desenvolvimento sustentável, além de impregnado de caráter eminentemente constitucional, encontra suporte legitimador em compromissos internacionais assumidos pelo Estado brasileiro e representa fator de obtenção do justo equilíbrio entre as exigências da economia e as da ecologia, subordinada, no entanto, a invocação desse postulado, quando ocorrente situação de conflito entre valores constitucionais relevantes, a uma condição inafastável, cuja observância não comprometa nem esvazie o conteúdo essencial de um dos mais significativos direitos fundamentais: o direito à preservação do meio ambiente, que traduz bem de uso comum da generalidade das pessoas, a ser resguardado em favor das presentes e futuras gerações".
} 
replaced by a sustainable logic and thus equitable access to resources is promoted lastingly. The Brazilian doctrinal law mentions the "principle of intergenerational equity", whose content provides man with the duty and responsibility to the future. It also emphasizes the link with the precautionary principle, given that this principle is a temporal projection instrument with respect to the variables involved in potentially degrading activities (LEITE; AYALA, 2002). The equity proposal reinforces the promotion of an ethics of intergenerational otherness, revealing the legal difficulty with using only normative criteria for assessing the transcendence of dimensions not only on space but also on time with regard to the transgenerational subject of the environment right (LEITE; AYALA, 2002). It is also noteworthy that intergenerational equity was based on three principles: the "principle of conservation options", according to which, each generation must appreciate the conservation of natural and cultural resources, allowing future generations to be able to evaluate the solution of their problems and meeting their needs. The second is the "principle of quality conservation", that would guarantee the right of future generations to enjoy a quality of planet, proportional, to the quality enjoyed by previous generations. Lastly, the "principle of conservation of access" in which each generation would have the obligation to allow its members to have the right to the legacy of past generations as well as the obligation to preserve access for future generations (LEITE; AYALA, 2002).

It is important to note that the main objective of this article is neither an analysis of the theory of sustainable development, nor a contribution to the debate about the ability of this theory to deconstruct the modern economic paradigm and limit effectively the new economic paradigms undertaken by a contemporary society. That is, to identifying sustainable development as a skilled instrument or not to promote the recognition of threats and contingencies called the "risk society". The aim is to demonstrate how the ideas of risk and sustainability are interrelated and how past, present and future form the acting scene of this "new subject" and the transgenerational right to the environment.

The constitutional consecration of the right to the environment as a fundamental right indicates more than an engagement with the sustainability of the planet. It suggests that after the duty imposed on the Government and the community to "defend and preserve it for present and future generations" (article 225 of the Brazilian Constitution of 1988), people not yet born now account by the Law as subjects of this right. It instituted a constitutional duty to preserve and, at the foundation of this duty, is solidarity as a limiter intergenerational bond. This suggests a break of the identified subject paradigm. This disruption ocurred not only because the subject now is 
presented in a non quantifiable way, but specifically, because of the possibility of a transgenerational subject, that operates at the same time with the present and future generations. Is this a paradox, as something that does not exist is being presented and protected by the Constitution? (SILVEIRA, 2007) Would the law be prepared to deal with the change in the subject and temporal dimensions? It is assumed that, from the construction of fundamental rights under the influence of individualism, there would be a natural difficulty of the realization of the right to the environment as a supportive duty. It means taking into account not only the immediate effects suffered due to environmental degradation, but also the long-term effects, which are likely to be experienced more intensely by future generations.

Once the solidarity acts as an intergenerational bond between the present and future generations who compose the subject of the right to environment, it is important to analyse how the Brazilian Supreme Court jurisprudence has interpreted this "new subject". In other words, how the future dimension of the right of the environment has been observed through the solidarity as a legal bond. Therefore, a search on the website of the Brazilian Supreme Court using the term "environment" was done using the offered search engine, delimiting the period between 1988 and 2008, corresponding to the first twenty years of the Constitution of Brazil. The aim was to develop the widest possible search, which was the reason for choosing the indicated expression; so that all decisions in environmental headquarters given in that period could be identified. The search resulted in 142 documents, but only 4 (four) decisions made reference to solidarity, which were respectively: MS 2.2164 - 1995 (Rel. Min. Celso de Mello); ADI-MC 3.540 - 2005 (Rel. Min. Celso de Mello); STA-AgR 171-2 - 2007 (Rel. Min. Ellen Gracie); STA-AgR 118-6 - 2007 (Rel. Min. Ellen Gracie).

The first decision states:

The right to integrity of the environment - typical right of third generation - is a legal right of collective ownership, reflecting, in the process of affirmation of human rights, the significant expression of a power attributed, not to the individual identified in its uniqueness, but in a sense truly comprehensive, the very social collectively (MS 2.2164, Rel. Min. Celso de Mello, judgment on 10.30.1995, plenary DJ 11.17.1995) ${ }^{10}$.

10 "O direito à integridade do meio ambiente - típico direito de terceira geração - constitui prerrogativa jurídica de titularidade coletiva, refletindo, dentro do processo de afirmação dos direitos humanos, a expressão significativa de um poder atribuído, não ao indivíduo identificado em sua singularidade, mas, num sentido verdadeiramente mais abrangente, à própria coletividade social". (MS 2.2164, Rel. Min. Celso de Mello, julgamento em 30-10-1995, Plenário, DJ de 17-11-1995). 
Here there is the recognition that the right to the environment presents itself as "transindividual", recognizing that its subject is collective. Finally, the following shows the passage in which the decision mentions the principle of solidarity:

While the rights of the first generation (civil and political rights) - which include the classic, negative or formal freedoms - emphasize the principle of freedom and the rights of second generation (economic, social and cultural) - who identify with the positive freedoms real or concrete - emphasize the principle of equality, third generation rights, which materialize collective ownership given generally to all social formations, enshrining the principle of solidarity and are an important moment in the development process, expansion and recognition of human rights, characterized as unavailable core values (MS 2.2164, Rel. Min. Celso de Mello, judgment on 10.30.1995, plenary DJ 11.17.1995) ${ }^{11}$.

Note that once again there was the exception with regards to collective ownership of the right to the environment, identified in the decision as the third generation. However, solidarity has been identified by the Supreme Court as a principle to be highlighted between the rights of third generation, despite the fact that the future impacts and risks involving the right to the environment have not been observed. The Court indeed stressed solidarity as a value of fundamental rights, but did not note the intergenerational limit, as a promotional mechanism of intergenerational equity. The "new subject", presented by the right to the environment, whose main feature is the "transgenerationality", was not considered in this section of the decision.

The second decision under consideration has the following sections:

THE PRESERVATION OF ENVIRONMENTAL INTEGRITY: CONSTITUTIONAL EXPRESSION OF A FUNDAMENTAL RIGHT OF GENERAL PEOPLE. Everyone has the right to an ecologically balanced environment. That is a typical right of the third generation (or brand new ones), who watches all mankind (RTJ 158 / 205-206). It is up to the State and the community itself, a special duty to defend and preserve, for the benefit of present and future generations, the right to collective ownership and transindividual character (RTJ 164 / 158161). The due performance of that charge, which is indispensable, is the guarantee that it will not be put in place, in the community within the serious intergenerational conflict marked by disregard for the duty of

11 "Enquanto os direitos de primeira geração (direitos civis e políticos) - que compreendem as liberdades clássicas, negativas ou formais - realçam o princípio da liberdade e os direitos de segunda geração (direitos econômicos, sociais e culturais) - que se identificam com as liberdades positivas, reais ou concretas acentuam o princípio da igualdade, os direitos de terceira geração, que materializam poderes de titularidade coletiva atribuídos genericamente a todas as formações sociais, consagram o princípio da solidariedade e constituem um momento importante no processo de desenvolvimento, expansão e reconhecimento dos direitos humanos, caracterizados, enquanto valores fundamentais indisponíveis". (MS 2.2164, Rel. Min. Celso de Mello, julgamento em 30-10-1995, Plenário, DJ de 17-11-1995). 
solidarity, imposed on everyone, the protection of this essential good of common use of people in general (ADI 3540-MC, Rel. Min. Celso de Mello, judgment on 01.09.2005, plenary DJ 02.03.2006) ${ }^{12}$.

The relationship between the preservation of the right to the environment and solidarity, as an instrument of promoting intergenerational equity, was starting to be considered in the jurisprudence of the Brazilian Supreme Court. Solidarity began to be identified as a means to avoid the mentioned intergenerational conflicts. Note that ten years have passed in order for solidarity to be mentioned, once again, by the Supreme Court. Thus emphasizing the role of intergenerational bond of the right to an ecologically balanced environment. In the above transcript excerpt, solidarity is recognized as duty. Thus, in addition to the third dimension of rights, the decision recognizes the solidarity as a duty on behalf of the right to an environment, which belongs to the people in general. This recognition confirms the thesis presented here that the transgenerational subject of the environment imposes a duty of solidarity where intergenerational equity can be allocated; the right to the environment presents a "new subject". On this decision, the court has begun to analyse of the future dimension of the right to the environment, in other words, it has contributed to the understanding, presented here, that the future of the environmental crisis has become present and the future subject is already part of this crisis.

The third decision to be analyzed pertains to the importation of used tires. In fact, two grievances were filed (AgR-STA 171-2 and 118-6 AgR-STA) which were judged in a single session, which will be analyzed here from the first text:

The due performance of that charge, which is indispensable, is the guarantee that it will not be put in place, in the community within the serious intergenerational conflict marked by disregard for the duty of solidarity, imposed on everyone, the protection of this essential good of

\footnotetext{
12 “A PRESERVAÇÃO DA INTEGRIDADE DO MEIO AMBIENTE: EXPRESSÃO CONSTITUCIONAL DE UM DIREITO FUNDAMENTAL QUE ASSISTE À GENERALIDADE DAS PESSOAS. Todos têm direito ao meio ambiente ecologicamente equilibrado. Trata- se de um típico direito de terceira geração (ou de novíssima dimensão), que assiste a todo o gênero humano (RTJ 158/205-206). Incumbe, ao Estado e à própria coletividade, a especial obrigação de defender e preservar, em benefício das presentes e futuras gerações, esse direito de titularidade coletiva e de caráter transindividual (RTJ 164/158-161). O adimplemento desse encargo, que é irrenunciável, representa a garantia de que não se instaurarão, no seio da coletividade, os graves conflitos intergeneracionais marcados pelo desrespeito ao dever de solidariedade, que a todos se impõe, na proteção desse bem essencial de uso comum das pessoas em geral (ADI 3.540-MC, Rel. Min. Celso de Mello, julgamento em 1-9-2005, Plenário, DJ de 3-2-2006)".
} 
common use of people in general (AgR-STA 171-2, Rel. Min. Ellen Gracie, judgment on 12/12/2007, Plenary, DJ 29-02-2008) ${ }^{13 .}$

The decision, therefore, affirms solidarity as a duty, indicating that if overlooked, runs the risk of provoking intergenerational conflicts. So, this is a brief mention of environmental solidarity but one that adds to the jurisprudential strength of the right to environment, which requires a caring and committed approach to future generations. It also contributes to the strengthening of intergenerational equity of a balanced environment, which reinforces the need to observe the "new subject" brought by the right to the environment. The future dimension of the right to the environment, albeit discreetly, becomes observed by the Court, which could reinforce the notion that the future of the environmental crisis needs to be analysed as a present time problem.

In this sense, considering environmental protection as a current liability of duty does not imply that the present generations are in a privileged position in terms of environmental awareness and, because of this privilege, would have the condition to decide what is best for future subjects. In fact, the point is to ensure the possibility of future choice, namely to promote the quality of life for generations yet to come. Even if the future generations were to decide for themselves that such is unnecessary or inadequate- they should still have the right to choose. For this choice to become possible, it is necessary to take on a stance of non-emergency on behalf of the "new subject", a transgenerational subject, and move from contemplation to responsibility, including the appreciation of the future dimension of the right to the environment by the jurisprudence. The future generations are at a disadvantage. Even their choices, in the future, are limited by the decisions taken by the generations that precede them; that are on many occasions represented by legal decisions like the ones analysed in this article. Its disadvantage is a reflection of one's vocal disability. The subjects of future generations lack the capacity to speak and often run the risk of having their interests overlooked by decisions, including judicial, which prioritize immediate results. These subjects have minimal bargaining power, and can do no harm or affect present generations (AGIUS, 2006). An interpretation of the law focused on the future, considering the risks experienced by the current society (SERRES, 2001), should not deny an intergenerational responsibility, considering that to take a supportive and precautionary approach will allow better future environmental conditions. Would it be required to the present generation to preserve the

\footnotetext{
13 "O adimplemento desse encargo, que é irrenunciável, representa a garantia de que não se instaurarão, no seio da coletividade, os graves conflitos intergeneracionais marcados pelo desrespeito ao dever de solidariedade, que a todos se impõe, na proteção desse bem essencial de uso comum das pessoas em geral (AgR-STA 171-2, Rel. Min. Ellen Gracie, julgamento em 12-12-2007, Plenário, DJ de 29-02-2008)".
} 
conditions for the survival of mankind? (BIFULCO, 2008) Is there an obligation to the future? (OST, 1997)

Given the fact that the implications caused by environmental degradation will be suffered by "a total subject" (SERRES, 1992), primarily by the unborn portion of this subject, the present time assumes a supportive and preventive role as well as the legal decisions taken by the Brazilian Jurisprudence. Thus, in view of the irreversibility of time, we cannot change the past and the uncertainty of the future and the present action become necessary and regenerating. The regenerative function of this time would act against the irreversibility of individualist heritage and future indeterminacy, which is one of the roles of the legal decisions in the right to the environment. In this sense, would the right to the environment suffer a tension between the paradigms of subjectivity and solidarity? That is, would the right to the environment be among the paradigms of individuality and humanity?

The questions raised here are far from being easily answered. This emphasizes in fact, the need for a legal regime that allows the dialectical character between man and nature, as opposed to one that only recognizes the domain of one over the other. This was influenced by contractual tradition and property scenario in which the subject of law was commonly involved. Therefore, the subject would need to take on a new dimension: responsibility towards future generations and equity in access to natural resources (OST, 1997), once the future of the environmental crisis is already present and the subject of its right is marked by a transgenerational feature.

\section{CONCLUSIONS: THE PRESENT WHICH THE FUTURE IS PART OF AND THE JURISPRUDENCE OF THE BRAZILIAN SUPREME COURT}

Modernity ended up creating "two worlds": "human" and "non-human". If on one hand human beings took on the role of subjects that make up "one of the modern worlds", on the other, natural order was taken as an object at our disposal, a second world to be appropriated by subjects that integrate the first. Human and non-human coexisted separately, "in different worlds", brought closer when one appropriated the other.

Thus, the modern production of domination of the natural order arises as one of the consequences of the end of the mysterious belief that magic and religion exerted on nature; the end of nature as a symbol of divine order and the end of man's quest for heaven. Regarded as a simple worthless raw substance, nature became the representation of an object to be exploited, an object for unlimited consumption. Man was not destituted of technologies. However, it is 
important to stress that modern technologies changed man's way of life. Furthermore, it resulted in the analysis of what can be considered a clash between the instincts of death and life, the difficult coexistence between the impulse to destroy elements of nature and the need to protect life itself.

The process of "repositioning" human behaviour towards nature has already been theorized. Examples of this are the confrontation between anthropocentric and nonanthropocentric points of view, the systemic discussion about man's role before the complexity of natural order and the defence of rights as a social control instrument. Regardless of the approaches raised by critical theory though time, the relationship between the subject of knowledge and its object was developed without any regard with the exchange between them. Thus, the "non-human" world was deemed to give without receiving in return, and a parasitic bond was established, deeming it necessary to rethink the possibility of a symbiosis due to the consequences of this parasitism. The increase of so-called collective interventions was considered one of the reasons for a critical reflection about on the lack of care of our peers, as well as with non-human elements. The relationship between actor, action and effects surpasses the limits of a nearby sphere, placing ethics in the dimension of future responsibility of a new subject, marked by non-proximity and the relationship with non-human elements, which should also be reflected on the jurisprudence. When considering that there was a shift both, in subjects and how they act, the thought of a crisis presents an ethical mission for a new concept of freedom. This ethical challenge is bypassed by the rupture of the common relationship of exclusive care of the human world, temporality limited by immediate descendants, expanding towards a future horizon, what in legal terms assumes the form of a "new subject" in the right to the environment, a transgenerational subject, which should be considered by the Court's decisions. The ethical debate that emerges from the crisis scenario proposes a human and non-human, where the future gains prominence along with the present. We are living in a state of crisis, where man has been driven away from the natural order. We are in a state of fear, and the results of this separation, which has been caused in the name of development, are unknown. We are living a present of which the future is already part of. This is a further understanding of the environmental crisis.

However, when the legal concern about the future and their subjects gained ground, environmental rights, consumer rights and the right to peace became part of the constitutional provisions of the second half of the twentieth century. Justified by the ideal of solidarity and the need for cooperative action, such rights, theoretically, overcame the subjectivist individual 
tradition. Aware of the problem of the projection of future generations in relation to an ecologically balanced environment and following the warning about the need for supportive and cooperative behaviour, the Brazilian Constitution established the duty of environmental preservation for present and future generations. But this prediction has raised another problem, which concerns the dominant paradigms in the law. The construction of a "new subject" in law, a transgenerational subject, not limited temporally, which brought some implications. Some of these are the proposal of sustainability, the duty of care and equity between generations, in other words, implications about the duty to the future.

In this sense, the norms of environmental law emerged as a limiting vehicle. They have, for the most part, aimed to impose limitations on human acts in the name of preventing damage. Environmental law is a kind of right of regulation of economic ownership of environmental goods. This appropriation will enable the sustainability of resources, as well as, economic and social development. The proposed durability thus implies in transmiting to future generations the capacity and resources contributing to a vision of a world in which the human relationship with nature can be given in a rational environmental way, even in crisis and risks scenarios. In fact, the responsibility for the actions that (potentially) cause damage to the environment seem to have invaded contemporary discourse. However, the question remains whether this presence already is recognized by Brazilian jurisprudence, with regard to the long-term consequences. In other words, it should be noted that the future dimension of the right to the environment has gained ground in decisions taken by the Brazilian Supreme Court. On the other hand, there is no denying that the presence of the solidarity expression, as an intergenerational bond between the present and future generations within the jurisprudence of the Supreme Court, is still limited, according to the analysis presented. The search done on the Brazilian Supreme Court's website used the term "environment" for a specific reason: to develop the widest possible search, delimiting the period between 1988 and 2008, corresponding to the first twenty years of the Constitution of Brazil. In this way, all decisions about the right to the environment, given in that period, could be identified. The result was a corpus, formed by 142 decisions. After having read through all these documents, only 4 (four) were identified as decisions which had mentioned the solidarity. In this group of four decisions, the future dimension of the right to the environment was observed superficially. It is not possible to find, on these first twenty years of Brazilian Supreme Court jurisprudence, a profound analyses about the complex subject of this right. The Court had not taken time to interpret the "new subject", brought into the law by the right to the environment. It is worth to note that 
throughout these ten years, constituting the period between the first and the second decisions analysed, the Brazilian Supreme Court had not interpreted the right to the environment through the solidarity as an intergenerational bond.

Therefore, what this article aims to highlight is the jurisprudential recognition that the subject of that right is composed, at the same time, by present and future generations as a mechanism. This instrument can help in the conversion of intergenerational responsibility, or, anticipation of responsibility in real actions in the transgenerational right to the environment. The future of the environmental crisis needs to be analysed in legal terms as a problem about a transgenerational subject, a "new subject" not only in a discreet way. The Brazilian Supreme Court has to confront the future dimension of the environmental law and act on it. The consequences that would be faced by the unborn subjects must be observed by the Court equally to the current ones. Present and future coexist, in terms of environmental crisis, and it must also coexist in legal terms, however, in the context of the Supreme Court this assumption seems to be an instrument under construction.

\section{REFERENCES}

AGIUS, Emmanuel. Intergenerational justice. In: TREMMEL, Joerg Chet. Handbook of intergenerational justice. Cheltenham: Edward Elgar, 2006.

AZEVEDO, Plauto Faraco de. Ecocivilização. Ambiente e direito no limiar da vida. São Paulo: Revista dos Tribunais, 2008.

BATAILLE, Georges. The accursed share. vol. 1. New York: Zone Books, 1988.

BAUMAN, Zygmunt. Modernidade líquida. Rio de Janeiro: Jorge ZAHAR, 2001. Identidade. Rio de Janeiro: Jorge ZAHAR, 2005.

CRITCHLEY, Simon. Infinitely demanding. Ethics of commitment, politics of resistance. Brooklyn: Verso, 2012.

FERRY, Luc. Le nouvel ordre écologique. L'arbre, l'animal et l'homme. Paris: Grasset, 2009. Développement durable, monde de la techinique et société du risque. In: BOITEUX, Marcel. L'homme et sa planète. Paris: PUF, 2003.

FRASER, Nancy. Behind Marx's hidden abode. For an expanded conception of capitalism. New Left Review n. 86, Mar./Apr. 2014, pp. 55- 72.

GABRIEL, Markus. Why the world does not exist. Cambridge: Polity, 2015. 
GARNIER, Christian. De La nature au dévelopement durable: La construction d'un concept pératoire. In: BOITEUX, Marcel. L'homme et sa planète. Paris: PUF, 2003.

GOUGUET, Jean-Jacques. Développement durable et décroissance. Deux paradigmes incommensurables. In: Pour un droit commun de l'environnement. Mélanges en l'honneur de Michel Prieur. Paris: Dalloz, 2007.

GORZ, André. Écologica. Paris: Galilée, 2008.

GUZMÁN, José López. Justicia y ecologia. In: BALLESTEROS, Jesús, RUIZ-GÁLVEZ, Maria Encarnación Fernández, MARTINÉZ-PUJALTE, Antonio-Luis (coords). Justicia, solidariedad, paz. Estudios en homenaje al Professor José María Rojo Sanz. Vol..l. Valencia: Departamento de Filosofía del Derecho, Moral y Política de la Universitat de València, 1995, pp. 231- 237.

HARVEY, David. Condição pós-moderna. Uma pesquisa sobre as origens da mudança cultural. São Paulo: Edições Loyola, 2013.

LARRÈRE, Catherine, LARRÈRE, Raphael. Du bon usage de la nature. Pour une philosophie de I'environnement. Paris: Flammarion, 2009.

LEFF, Enrique. Racionalidade ambiental - a reapropriação social da natureza. Rio de Janeiro: Civilização Brasileira, 2006.

LEITE, José Rubens Morato, AYALA, Patryck de Araújo. Direito ambiental na sociedade de risco. Rio de Janeiro: Forense Universitária, 2002.

LUKE, Tim. Marcuse's ecological critique and the American environmental movement. In: ABROMEIT, John, COBB, W. Mark (orgs.). Herbert Marcuse. A critical reader. New York: Routledge, 2004, pp. 236-239.

LYOTARD, Jean-François. The Inhuman. Reflections on time. Cambridge: Polity Press, 1991.

MARX, Karl, ENGELS, Friedrich. The communist manifesto. In: The Marx-Engels Reader. London: Norton, 1978.

MORIN, Edgar. O método. 1. A natureza da natureza. Mira-Cintra: Publicações Europa-America, 1977.

MOORE, Jason W. Capitalism in the web of life. Ecology and accumulation of Capital. New York: Verso, 2015.

Disponível

De objeto a Oikeios: la construcción del ambiente en la ecología-mundo capitalista.

http://www.jasonwmoore.com/uploads/Moore_DE_OBJETO_A_OIKEIOS_2015.pdf

Accessed in: 02/25/2016

NORTON, Bryan G. L'éthique environnementale et I'anthropocentrisme faible. In: AFEISSA, H. S. Éthique de l'environnement. Nature, valeur, respect. Paris: VRIN, 2007. 
NIETZSCHE, Friedrich. Thus In: https://en.wikisource.org/wiki/Thus_Spake_Zarathustra/Prologue Accessed in: 04/04/2016.

OST, François. A natureza à margem da lei. A ecologia à prova do direito. Lisboa: Instituto Piaget, 1997.

PIERRON, Jean-Philippe. Penser le développement durable. Paris: Ellipses, 2009.

SACHS, Ignacy. Primeiras intervenções. In: NASCIMENTO, Elimar Pinheiro do, VIANNA, João Nildo (orgs.) Dilemas e desafios do desenvolvimento sustentável no Brasil. Rio de Janeiro: Garamond, 2009.

SERRES, Michel. Le contrat naturel. Paris: Flammarion, 1992.

Hominescence. Paris: Le Pommier, 2001.

SMOUTS, Marie-Claude. Le développement durable: valeurs et pratiques. In: SMOUTS, MarieClaude. Le développement durable. Lês termes du débat. Paris: Armand Colin, 2008.

STENGERS, Isabelle. No tempo das catástrofes - resistir à barbárie que se aproxima. São Paulo: Cosac Naify, 2015.

SILVEIRA, Júlio Cesar Costa da. Gerações futuras: devir, paradoxo e fundamento. In: BENJAMIN, Antonio Herman, LECEUY, Eladio, CAPELLI, Sílvia (Org.). Meio ambiente e acesso à justiça: flora, reserva legal e APP. Vol. 03. São Paulo: Imprensa Oficial do Estado de São Paulo, 2007.

THACKER, Eugene. In the dust of this planet. Horror of philosophy vol. 1. Alresford: Zero books, 2011.

WHITESIDE, Kerry H. Une écologie humaniste. In: SMOUTS, Marie-Claude. Le développement durable. Lês termes du débat. Paris: Armand Colin, 2008.

Trabalho enviado em 07 de abril de 2016.

Aceito em 07 de abril de 2016. 